\title{
KANDUNGAN PROTEIN KASAR DAN SERAT KASAR PADA DAUN KANGKUNG AIR (Ipomoea aquatica) YANG DIFERMENTASI \\ CRUDE PROTEIN CONTENT AND CRUDE FIBER ON WATERCRESS LEAF WATER (Ipomoea aquatica) IN FERMENTED PROCESSING
}

\author{
Agustono, Andy Setyo Widodo dan Widya Paramita \\ Fakultas Perikanan dan Kelautan Universitas Airlangga \\ Kampus C Mulyorejo - Surabaya, 60115 Telp. 031-5911451
}

\begin{abstract}
Watercress leaf water availability (Ipomoea aquatica) in the aquatic environment, can be use as feed supplement, because it has enough protein, but the content is very high crude fiber. Fermentation is a good way to improve the value of water content of watercress leaf water.

The purpose of this research to increase the protein content and lower crude fiber content levels. The study was conducted in the Animal Husbandary Departement Faculty of Veterinery Medicine of Airlangga University.

This research used watercress leaf water and probiotics as fermenters. Treatments is used 5 with the size of different doses of probiotics, namely P0 (0\%), P1 (2\%), P2 (4\%), P3 (6\%), and P4 (8\%), of each treatment is repeated 4 times, and the fermentation process carried out for 7 days, then analysed proximat. Experimental design used is Complete Random Design (RAL). Analysis of data using various print and to determine the best treatment performed Duncan's Multiple Range test.

The result showed that the use of probiotics in the fermentation process watercress leaf water the real impact of increased crude protein and crude fiber decreased. Crude protein content increased from 23,9945\% (P0) to 28,1079 (P4). Crude fiber decreased from $16.1744 \%$ (P0) to $11.8341 \%(\mathrm{P} 3)$. The use of probiotics are most effective in the fermentation process watercress leaf water at doses of $8 \%$.
\end{abstract}

Key words : crude protein, crude fiber, Ipomoea aquatica, fermentation

\section{Pendahuluan}

Kegiatan usaha budidaya perikanan, tidak terlepas dari kebutuhan pakan. Pakan merupakan faktor yang banyak membutuhkan biaya, yaitu 60-70\% dari seluruh biaya produksi (Imansyah, 2005). Mahalnya harga pakan ikan tidak terlepas dari harga bahan pembuat pakan yang ada (Kurnia, 2008). Peningkatan harga bahan pakan yang terjadi pada akhir-akhir ini membuat keuntungan semakin berkurang (Ermawati, 2008). Pengembangan penelitian sekarang yang sangat diperlukan diantaranya adalah protein asal tumbuhan (Kurnia, 2008). Daun kangkung air merupakan salah satu bahan pakan asal tumbuhan (Novianti, 2008). Bahan pakan ini berharga murah, mudah didapatkan, dan memiliki kandungan nutrisi pakan yang cukup serta dapat menguntungkan (Hardianto, 2004).

Menurut Suraya (2006) pada bidang perikanan daun kangkung air selama ini digunakan sebagai bahan pakan ikan, serta dapat digunakan sebagai alternatif bahan pakan diantaranya sebagai suplemen bahan pakan pada ikan wader (Rasbora argyrotaenia) (Budiharjo, 2007). Vromant et al. (2002) menambahkan daun kangkung merupakan sumber hijauan yang disenangi oleh ikan nila, tetapi Hidayati (2005) menambahkan penggunaan daun kangkung ini kurang optimal karena masih dianggap gulma bagi beberapa pembudidaya dan daun kangkung air hanya berupa limbah (Lestari dkk., 2008). Bentuk limbah ini dikarenakan daun kangkung air memiliki nilai kandungan nutrisi serat kasar yang tinggi (Nainggolan dkk., 2005). Ramuan dalam pembuatan pakan ikan, kadar serat kasar tidak baik jika bernilai tinggi (Mudjiman, 2004). Cara mengoptimalkan kadar kandungan serat kasar daun kangkung air diantaranya dengan fermentasi (Syamsu, 2007).

Fermentasi merupakan kemajuan bioteknologi dengan memanfaatkan mikroba dan merupakan cara alternatif optimalisasi daur ulang limbah pertanian (Muis dkk., 2008). Fermentasi digunakan untuk mengoptimalkan daun kangkung air dalam meningkatkan protein kasar serta menurunkan 
serat kasar (Malik, 2008). Hasil fermentasi diharapkan terjadi adanya peningkatan komposisi bahan pakan dan mampu meningkatkan pertumbuhan ikan (Widiastuti, 2007). Fermentasi merupakan kegiatan mikroba pada bahan pakan sehingga dihasilkan produk yang dihendaki (Hidayat dkk., 2007) dan dibantu oleh beberapa mikroba yang bekerja diantaranya enzim proteolitik dan selulolitik. Mikroba ini dapat merombak protein serta mendegradasi serat kasar agar bahan pakan dapat digunakan secara optimal (Rusianto, 2009).

Penelitian sebelumnya, penggunaan probiotik dengan dosis $4 \%$, memberikan hasil terbaik yang dapat meningkatkan protein kasar dan menurunkan serat kasar pada jerami padi yang terfermentasi selama 7 hari (Rifqiyah, 2005).

Hasil fermentasi daun kangkung air yang diharapkan dapat memperkaya bahan pakan, serta dapat digunakan sebagai bahan pakan tambahan alternatif yang dapat meningkatkan pertumbuhan ikan. Penelitian ini sangat penting dilakukan, untuk meningkatkan kandungan protein dan menurunkan kandungan serat kasar pada daun kangkung air, sehingga dapat digunakan untuk bahan pakan.

Tujuan dari kegiatan ini adalah mengetahui pengaruh fermentasi terhadap kandungan protein kasar daun kangkung air, selain itu mengetahui pengaruh fermentasi terhadap kandungan serat kasar daun kangkung air.

\section{Materi dan Metode Penelitian}

Penelitian ini dilaksanakan di Laboratorium

Pakan Ternak Hewan Universitas Airlangga, Surabaya, pada tanggal 20 Juli - 24 Agustus 2009. Penelitian ini bersifat eksperimental. Rancangan percobaan yang digunakan adalah Rancangan Acak Lengkap (RAL) dengan 5 perlakuan dan 4 kali ulangan. Data penelitian akan dianalisis dengan Rancangan Acak Lengkap menggunakan Sidik Ragam dilengkapi dengan adanya tranformasi $(\sqrt{ }$ y) karena data yang diperoleh berada dalam wilayah 0-30\%, dilanjutkan dengan Uji Jarak Berganda Duncan (Duncan's Multiple Range Test 5\%) untuk menentukan perlakuan mana yang berbeda dengan perlakuan lain serta mencari hasil terbaik diantara perlakuan (Kusriningrum, 2008).

\section{Hasil dan Pembahasan}

Hasil rata-rata kandungan protein kasar kangkung air yang telah terfermentasi dengan menggunakan probiotik dapat dilihat pada Tabel 1.

Berdasarkan hasil analisis statistik dengan menggunakan Analisis Varian (Anava) dapat diketahui bahwa dosis probiotik pada fermentasi daun kangkung air berpengaruh nyata terhadap kandungan protein kasar daun kangkung air.

Berdasarkan hasil uji Duncan dapat diketahui bahwa kandungan protein kasar tertinggi terdapat pada perlakuan P4 (8\%). Perlakuan P4 (8\%) berbeda nyata dengan perlakuan P3 $(6 \%)$, perlakuan $\mathrm{P} 2$, perlakuan P1, dan P0. Perlakuan P3 (6\%) tidak berbeda nyata terhadap perlakuan P2 (4\%). Perlakuan P2 (4\%) tidak berbeda nyata dengan perlakuan P1 (2\%). Perlakuan P1 (2\%) tidak berbeda nyata dengan P0 (0\%). Hasil terendah pada perlakuan P0 $(0 \%)$ yang tidak berbeda dengan P1 (2\%). Perlakuan P4 (8\%) berbeda nyata terhadap perlakuan $\mathrm{P} 0(0 \%)$.

Rata-rata kandungan protein kasar daun kangkung air yang telah di fermentasi dengan

Tabel 1. Rata-rata kandungan protein kasar daun kangkung air setelah difermentasi berdasarkan bahan kering

\begin{tabular}{|c|c|c|}
\hline Dosis perlakuan (\%) & $\begin{array}{c}\text { Kandungan protein }(\%) \\
\text { rata-rata } \pm \text { SD }\end{array}$ & $\begin{array}{c}\text { Transformasi }(\sqrt{ } \mathrm{Y}) \\
\text { rata-rata } \pm \text { SD }\end{array}$ \\
\hline P0 ( 0 \%) & $23,9945 \pm 0,6674$ & $4,8980^{\mathrm{d}} \pm 0,0684$ \\
P1 ( 2\%) & $25,1111 \pm 0,3052$ & $5,0110^{\text {cd }} \pm 0,0305$ \\
P2 ( 4 \%) & $26,3742 \pm 0,5573$ & $5,1353^{\mathrm{bc}} \pm 0,0543$ \\
P3 ( 6\%) & $26,7711 \pm 1,1800$ & $5,1731^{\mathrm{b}} \pm 0,1133$ \\
P4 ( $8 \%)$ & $28,1079 \pm 1,2484$ & $5,3007^{\mathrm{a}} \pm 0,1177$ \\
\hline
\end{tabular}

Keterangan : superskrip berbeda pada kolom yang sama menunjukkan perbedaan yang nyata dengan uji jarak Duncan (5\%) 
menggunakan probiotik (P1,P2,P3,P4) mengalami peningkatan bila dibandingkan dengan daun kangkung air yang difermentasi tanpa menggunakan probiotik (P0). Kandungan protein kasar tersebut berturut-turut adalah 23,9945\%, 25,1111\%, 26,3742\%, 26,7711\%, dan $28,1079 \%$. Grafik rata-rata peningkatan kandungan protein kasar ini dapat dilihat pada Gambar 1.

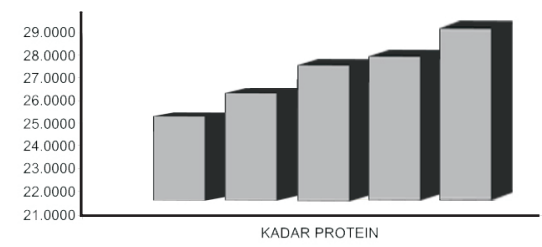

Gambar1. Grafik rata-rata peningkatan kandungan protein kasar daun kangkung air

Hasil rata-rata kandungan serat kasar daun kangkung air yang telah difermentasi dengan menggunakan probiotik dapat dilihat pada Tabel 2.

Berdasarkan hasil analisis statistik dengan menggunakan Anava dapat diketahui bahwa penggunaan probiotik pada proses fermentasi daun kangkung air berpengaruh nyata terhadap kandungan serat kasar daun kangkung air.

Hasil Uji Duncan menunjukkan bahwa kandungan serat kasar terendah adalah pada perlakuan P3 (6\%) yang tidak berbeda nyata dengan perlakuan P4 (8\%) dan P2 (4\%). Perlakuan P2 (4\%), P3 (6\%) dan P4 ( $8 \%$ ) berbeda nyata dengan perlakuan P1 (2\%).
Perlakuan P0 (0\%) menunjukkan hasil serat kasar tertinggi. Kandungan serat kasar daun kangkung air yang difermentasi dengan menggunakan probiotik (P1,P2,P3) mengalami penurunan bila dibandingkan dengan daun kangkung air yang difermentasi tanpa menggunakan probiotik (P0). Rata-rata penurunan kandungan serat kasar pada perlakuan (P0, P1, P2, P3, P4) secara berturut-turut adalah 16,1744\%, 13,5448\%, $12,5915 \%, 11,8341 \%$, dan $11,9789 \%$. Grafik rata-rata penurunan kandungan serat kasar dapat dilihat pada Gambar 2.

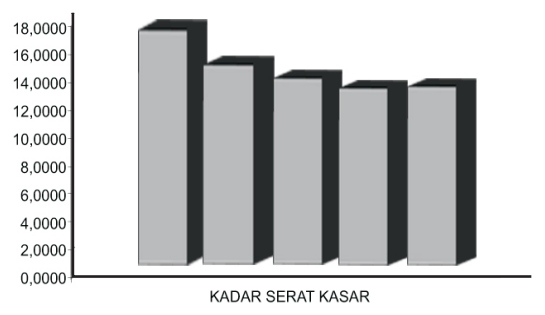

Gambar 2. Grafik rata-rata penurunan kandungan serat kasar

Hasil penelitian menunjukkan bahwa fermentasi daun kangkung air menggunakan probiotik selama 7 hari dapat meningkatkan kandungan protein kasar dari 23,9945\% (P0) menjadi 28,1079\% (P4) (Tabel 1). Kandungan Protein kasar yang meningkat disebabkan oleh adanya peningkatan jumlah biomasa mikroba. Hal ini sesuai dengan (Hau dkk., 2005) peningkatan nilai protein berdampak positif terhadap produksi protein mikroba.

Tabel 2. Rata-rata kandungan serat kasar daun kangkung air terfermentasi berdasarkan bahan kering

\begin{tabular}{|c|c|c|}
\hline $\begin{array}{c}\text { Dosis probiotik } \\
(\%)\end{array}$ & $\begin{array}{c}\text { Kandungan serat kasar }(\%) \\
\text { rata-rata } \pm \text { SD }\end{array}$ & $\begin{array}{c}\text { Transformasi }(\sqrt{ } \mathrm{Y}) \\
\text { rata-rata } \pm \text { SD }\end{array}$ \\
\hline P0 ( $\%)$ & $16,1744 \pm 0,9507$ & $4,0204^{\mathrm{c}} \pm 0,1179$ \\
P1 ( 2\%) & $13,5448 \pm 0,3991$ & $3,6800^{\mathrm{b}} \pm 0,0538$ \\
P2 ( $\%)$ & $12,5915 \pm 0,4907$ & $3,5479^{\mathrm{a}} \pm 0,0698$ \\
P3 ( $\%)$ & $11,8341 \pm 0,5727$ & $3,4392^{\mathrm{a}} \pm 0,0836$ \\
P4 ( $\%$ ) $)$ & $11,9789 \pm 0,4885$ & $3,4605^{\mathrm{a}} \pm 0,0702$ \\
\hline
\end{tabular}

Keterangan : superskrip berbeda pada kolom yang sama menunjukkan perbedaan yang nyata dengan uji jarak Duncan (5\%) 
Mikroba proteolitik yang terdapat dalam probiotik adalah Bacillus sp dan Streptomyces. Menurut Thomas dkk (1987) mikroba ini mampu menghasilkan enzim protease yang akan merombak protein. Anggorodi (1994) menambahkan perombakan protein diubah menjadi polipeptida, selanjutnya menjadi peptida sederhana, kemudian peptida ini akan dirombak menjadi asam-asam amino. Asam-asam amino ini yang akan dimanfaatkan oleh mikroba untuk memperbanyak diri. Jumlah koloni mikroba yang merupakan sumber protein tunggal menjadi meningkat selama proses fermentasi. Proses tersebut secara tidak langsung dapat meningkatkan kandungan protein kasar(Wuryantoro, 2000).

Perlakuan penelitian ini dilakukan secara aerob, yang menggunakan oksigen dalam prosesnya. Proses aerob pada perlakuan dilakukan dengan cara membuka tutup plastik tempat proses fermentasi berlangsung. Hal ini sesuai dengan Afrianti (2009) proses fermentasi aerob menggunakan oksigen untuk mencerna glukosa untuk menghasilkan air, karbondioksida dan sejumlah besar energi.

Penguraian materi berlangsung dengan reaksi enzimatik (Waluyo, 2005). Sebagian besar reaksi kimia dalam sel-sel hidup berlangsung sangat lambat bila tidak dikatalisis oleh enzim (Hariati, 1989). Adanya mikroba proteolitik yang mampu menghasilkan enzim protease menyebabkan pemecahan protein berlangsung lebih cepat (Priskila, 2007).

De jong, et al (1991) menyatakan bahwa tingginya kadar karbohidrat dan mineral tetes tebu (molases) diharapkan mampu menstimulasi pertumbuhan mikroba. Perkembangan dari mikroba tergantung pada karbon yang tersedia, dengan meningkatnya jumlah mikroba tersebut maka akan terjadi kompetisi diantara mikroba untuk mendapatkan karbon, sehingga ketersediaan karbon menjadi faktor pembatas (Rifqiyah, 2005). Dijelaskan kembali menurut Afrianti (2009) proses metabolisme yang dilakukan bakteri membutuhkan sumber energi berupa karbohidrat, protein, lemak, yang terdapat pada pakan. Aktifitas mikroba dalam proses fermentasi mengarah pada karbohidrat kemudian protein dan lemak.

Peningkatan kandungan protein pada perlakuan menunjukkan bahwa terdapat peningkatan aktifitas bakteri proteolitik dalam mengikat $\mathrm{N}$. Matthewman (1994) menyatakan bahwa nitrogen adalah bahan dasar untuk sintesis protein bakteri. Bakteri yang tumbuh dapat digunakan untuk membantu mengoptimalkan pakan yang digunakan untuk ternak (Buckle dkk, 1987).
Perlakuan yang menunjukkan hasil terbaik dengan kandungan protein tertinggi pada perlakuan P4 (28,1079\%). Perlakuan P4 (8\%) mempunyai jumlah dosis probiotik telah mencukupi dibanding dengan perlakuan P1, P2, dan P3, sehingga jumlah mikrobanya lebih banyak bila dibanding dengan perlakuan P1, P2, dan P3 yang menyebabkan aktifitas mikroba dalam mensintesis protein juga lebih tinggi. Meningkatnya nilai protein terhadap bahan pakan, memberikan indikasi bahwa energi yang tersedia cukup tinggi (Krisnan dkk., 2005).

Hasil penelitian menunjukkan bahwa terjadi penurunan kandungan serat kasar yang difermentasi (Tabel 2). Menurunnya kandungan serat kasar daun kangkung air terfermentasi disebabkan pada penelitian ini mengandung mikroba Cellulomonas sp. Mikroba ini dapat mendegradasi bahan organik seperti serat kasar.

Serat kasar merupakan selulosa yang digunakan sebagai penyusun dinding sel tanaman yang sukar didegradasi karena monomer glukosa dihubungkan pada suatu ikatan. Beberapa bakteri ada yang dapat melakukan pemecahan ikatan tersebut yaitu mikroba selulolitik (Heriyanto, 2008). Adanya degradasi karbohidrat membuat adanya penyederhanaan perubahan dari selulosa menjadi selubiosa dengan bantuan enzim selulase, selanjutnya selubiosa disederhanakan menjadi glukosa (Wiria, 1996).

Proses fermentasi pada perlakuan menggunakan bakteri selulolitik yaitu Cellulomonas dan Actinomyces. Hasil perlakuan terbaik adalah nilai kandungan nutrisi serat kasar terendah. Serat kasar terendah terdapat pada perlakuan P3(6\%), tetapi tidak berbeda nyata dengan $\mathrm{P} 2(4 \%)$ dan $\mathrm{P} 4(8 \%)$, namun berbeda nyata terhadap $\mathrm{P} 0(0 \%)$ dan $\mathrm{P} 1(2 \%)$. Hal ini disebabkan pada perlakuan $\mathrm{P} 3(6 \%)$ terjadi akibat biomassa mikroba telah mencapai nilai maksimum, dengan demikian diikuti dengan nilai nutrisi sudah tidak sebanding dengan jumlah biomassa, yang mengakibatkan semakin lama biomassa semakin berkurang (Kanti, 2005). Adanya penurunan tersebut diakibatkan aktifitas enzim selulase telah mencapai waktu inkubasi optimum (Gal et al., 1997).

Penambahan dosis probiotik akan menyebabkan populasi mikroba yang semakin banyak sehingga mampu mendegradasi komponen selulosa secara optimal. Kandungan dosis $8 \%$ terdapat jumlah mikrobia sesuai dengan substrat yang ada dan kondisi yang sesuai dengan mikroorganisme pemecah selulosa. 
Penambahan dosis tersebut pada pakan dapat meningkatkan daya cerna (Forsberg et al., 2004). Pemberian probiotik pada perlakuan secara khusus dapat meningkatkan kecernaan serat, sehingga dapat menurunkan kadar nutrisi serat kasar (Heriyanto, 2008; Charles, 2005). Sejalan dengan hal ini, Murtidjo (2001) menyatakan bahwa tinggi rendahnya kecernaan zat-zat makanan pada ikan bergantung pada kualitas protein ransum melainkan pada kandungan serat kasar dan aktifitas mikroorganisme terutama bakteri selulolitik. Aktifitas mikroba selulolitik tersebut dengan cara mengeluarkan enzim selulase yang berfungsi untuk menghancurkan adanya ikatan lignoselulosa yang telah didegradasi. Proses tersebut mengakibatkan sumber $\mathrm{N}$ dalam bahan pakan berupa serat terlepas dari ikatan, sehingga dapat dicerna secara maksimal (Hau dkk., 2005).

\section{Kesimpulan}

Fermentasi memberikan pengaruh nyata terhadap nilai kandungan protein kasar daun kangkung air yaitu peningkatan dari $23,9945 \%$ menjadi $28,1079 \%$.

Fermentasi memberikan pengaruh nyata terhadap nilai kandungan serat kasar daun kangkung air yaitu penurunan dari 16,1744\% menjadi 11,8341\%.

Berdasarkan hasil penelitian yang telah dilakukan, maka penulis menyarankan melakukan penelitian lebih lanjut pemberian pakan daun kangkung yang telah difermentasi dengan probiotik pada budidaya ikan sebagai hewan coba, untuk mengetahui pengaruhnya terhadap konsumsi, kecernaan dan pertambahan berat badan.

\section{Daftar Pustaka}

Afrianti, LH. 2009. Excellence Of Food Ferment (Keunggulan Makanan Fermentasi). http://www.wordpress.com. 20/8/2009.

Anggorodi, 1994. Ilmu Makanan Ternak Umum. Gramedia Pustaka Utama Jakarta.

Buckle, K.A., R.A, Edward., G.H. Fleet and M.Wotton. 1987. Ilmu Pangan. Penerjemah : Hari Purnomo dan Adiono. Universitas Indonesia. Jakarta.

Budiharjo, A. 2007. Application of Food Suplement For Increasing Growth of Wader Fish (Rasbora argyrotaenia). Skripsi. Jurusan Biologi. Fakultas Matematika Ilmu Pengetahuan Alam. Universitas Surakarta. Solo.
Charles. 2005. Pembahasan Umum. Laboratorium Agrostologi IPB Dermaga. Institut Pertanian Bogor. Bogor.

De jong, R., Van rucem.J., Ibrahim, M.N.M., and H. Purnomo. 1991. Livestock and Feed Development in the Tropics. Agricultural University. Waginingen. Netherland.

Ermawati, R. 2008. Harga Pakan Terus Melejit, Petani Ikan Megap-megap www.solopos.com. 17/10/2008.

Fardiaz, S. 1993. Analisa Mikrobiologi Pangan. PT. Raja Grafindo Persada. Jakarta.

Forsberg, C.W., E. Forano, and A. Chesson. 2004. Microbiol Adherence to the Plant Cell Wall and Enzymatic Hydrolysis. In : P.B. Cronje (ed). Ruminant Physiology. CABI Publishing.

Gal, L., S. Pages, C. Gaudin, A. Belaich, C. Reverbelleroy, C. Tardif, and J.P.Belaich. 1997. Characterization of the cellulolytic complex (Cellulosome) produced by Clostridium cellulolyticum. Applied Environmental Microbiology, 63 (3): 903-909.

Hardianto, R. 2004. Pemanfaatan Limbah pertanian \& Aroindustri sebagai bahan baku untuk pengembangan industri pakan ternak compleed feed. Program magang \& Transfer Teknologi pakan. Balai Pengkajian Teknologi Pertanian. Jawa Timur.

Hariati, A.M. 1989. Diktat Kuliah Makanan Ikan. Fish Fisheries Project. Fakultas Perikanan. Universitas Brawijaya. Malang.

Hau, D.K., M. Nenobais., J. Nulik., N. Athan dan G.F. Katipana. 2005. Pengaruh Probiotik Terhadap Kemampuan Cerna Mikroba Rumen Sapi Bali. Seminar Nasional Teknologi Peternakan dan Veteriner. Balai Pengkajian Teknologi Pertanian. Nusa Tenggara Timur. Universitas Nusa Cendana. Kupang.

Heriyanto. 2008. Probiotik (Migrosuplemen/MIG Ternak) Departemen Pertanian Direktorat Jendral Bina Produksi Peternakan Balai Besar Pengujian Mutu \& Sertifikasi Obat Hewan No B.0264. Bogor. Indonesia.

Hidayat, N, M.C.Padaga, dan S.Suhartini. 2007. Fermentasi. Pengembangan Produk danTeknologiProses. www.hidayat. wordpress. com.8/6/2009.

Hidayati, N. 2005. Fitoremediasi dan potensi tanam hiperkumulator. Jurnal bio sains hayati. I (12) :35-40. 
Imansyah, B.S. 2005. Mendaur Ulang Limbah Jadi Konsumsi Ternak. http://agrobis.com. 6/6/2009.

Kanti, A. 2005. Actinomyces Selulolitik dari Tanah Hutan Taman Nasional Bukit Duabelas, Jambi. Bidang Mikrobiologi. Pusat Penelitian Biologi, Lembaga Ilmu Pengetahuan Indonesia (LIPI). Biodiversitas, 6(2):85-89.

Krisnan, R., S.P.Ginting. 2005. Produktivitas Kambing Kacang Dengan Pemberian Pakan Komplit Kulit Buah Markisa (Passiflora edulis sims. F. edulisdeg) Terfermentasi Aspergillus niger. Seminar Nasional Teknologi Peternakan dan Veteriner. Loka Penelitian Kambing Potong. Sumatra Utara.

Kurnia, A. 2008. Dicari Pakan Ikan Berkualitas, Murah d a n R a m h L i n g u n g n . http://www.iptek.net/artikeliptek. 12/11/2008.

Kusriningrum. 2008. Dasar Perancangan Percobaandan Rancangan Acak Lengkap. Airlangga University Press. Surabaya.

Lestari, S.C.M., H.I. Wahyuni., dan L. Susandari. 2008. Budidaya Kelinci Menggunakan Pakan Limbah Industri Pertanian Dan Bahan Pakan Inkonvensional. Lokakarya Nasional Potensi dan Peluang Pengembangan Usaha Agribisnis Kelinci. Fakultas Peternakan. Universitas Diponegoro. Semarang.

Malik, T. 2008. Ketersediaan Sulfur Tanah dan Sumbernya. http://www.indoskripsi.com. 6/6/2009.

Mathewman R. 1994. A manual of Tropical Ruminant Nutrition And Feeding. CTUM. Scotland. UK.

McDonald, P., R. A. Edwards and J.F.D. Greenhalg. 1988. Animal Nutrition. 4th Ed. Longman Scientific and Technical. New York.

Mudjiman, A. 2004. Makanan Ikan Edisi Revisi. Penebar Swadaya.Jakarta.

Muis, A, Khairani, C, Sukarjo, Rahardjo, Y.P. 2008. Petunjuk Teknis Teknologi Pendukung Pengembangan Agribisnis di Desa P4MI. Badan Penelitian Dan Pengambangan Pertanian. Balai Pengkajian Teknologi Pertanian. Sulawesi Tengah.

Murtidjo, B.A. 2001. Pedoman Meramu Pakan Ikan. Kanisius. Yogyakarta.
Nainggolan,O dan Adimunca, C. 2005. Diet Sehat Dengan Serat. Pusat Penelitian Dan pengembangan Pemberantasan Penyakit. Badan Penelitian Dan Pengembangan Kesehatan Departemen Kesehatan RI Jakarta. Cermin Dunia Kedokteran 147.

Novianti, K. 2008. Asal-usul Botanis Sayuran dan Buah-Buahan. Artikel. Widyaiswara Balai Besar Pelatihan Pertanian Lembang. Lembang.

Priskila, F. 2007. Pengaruh Penggunaan Kombucha Terhadap Kandungan Protein Kasar dan Serat Kasar pada Fermentasi Daun Talas (Colocasia esculenta). Skripsi. Program Studi S-1 Budidaya Perairan. Fakultas Kedokteran Hewan. Universitas Airlangga. Surabaya.

Putra, S. 2008. Pengaruh Suplementasi Beberapa Sumber Mineral Dalam Konsentrat Terhadap Serapan, Retensi, Utilisasi Nitrogen, dan Protein Darah Kambing Peranakan Etawah Yang Diberi Pakan Dasar Rumput. Jurusan Nutrisi Dan Makanan Ternak. Fakultas Peternakan. Universitas Udayana.Bali.

Rifqiyah, N. 2005. Pengaruh Pemberian Probiotik Pada Jerami Padi Terhadap Kandungan Protein Kasar dan Serat Kasar. Skripsi. Fakultas Kedokteran Hewan. Unair. Surabaya.

Rusianto, N. 2009. Teknologi Pakan Dalam Penggemukan Sapi Secara Intensif. http://psmgroup.blogspot.com. 8/6/2009.

Suraya, 2006. Kelimpahan dan Keanekaragaman Tumbuhan Air Di Perairan Danau Tabiri. Jurusan Manajemen Perikanan Sumberdaya Perairan. Fakultas Pertanian. Universitas Palangkaraya. Kalimantan Barat.

Syamsu, J.A. 2007. Teknologi Pengolahan Jerami Padi Sebagai Pakan Ternak. Skripsi. Jurusan Nutrisi dan Makanan Ternak. Fakultas Peternakan. Universitas Hasanudin. Makasar. Sulawesi Selatan.

Thomas TD and Pritchard GG. 1987. Proteolytic Enzymes From Dairy Starter Cultures. Fed. Eur. Microbiol. Soc. Microbiol. Rev. 46 : 245.

Vromant, N., C.Q. Nam., F. Oliver. 2002. Growth Performance of Barbodes Gonionotus (Bleeker in intensively cultivated rice field. Vietnam. Elsevier : Aquaculture 212 : 167178. 
Waluyo, L. 2005. Mikrobiologi Lingkungan. UMM Press.Malang.

Widiastuti,R.R. 2007. Formulasi Pakan Buatan Dengan Teknologi Fermentasi Pada Budidaya Ikan Nila (Oreochromis niloticus Linn). Jurusan SITH-ITB. Bandung.

Wiria, U.S. 1996. Mikrobiologi Air dan Dasar-Dasar Pengolahan Buangan Secara Biologis. PenerbitAlumni. Bandung.
Wuryantoro, S. 2000. Kandungan Protein Kasar dan Serat Kasar Hay Padi Teramonisasi yang difermentasi dengan cairan Rumen. Skripsi. Fakultas Kedokteran Hewan. Universitas Airlangga. Surabaya. 